\title{
DO LOYALTY CARDS ENHANCE LOYALTY IN THE PHARMACEUTICAL SECTOR?
}

\begin{abstract}
This paper aims to analyze the influence of the "Portuguese Pharmacies card" (PP card) on the pharmacies' customers behaviour. It also intends to examine whether marketing stimuli influence consumers' buying behavior with regard to non-prescription medicines / health and wellness product / pharmaceutical services (NP/HW/PS) and to understand if the consumer social-demographic characteristics influence purchase decisions and customers' loyalty.

The investigation is based on the results obtained through an online survey. Exploratory descriptive analysis, based on a sample of 385 customers, is used to empirically verify the hypothesis under study.

The Marketing of stimuli considered in this research include four communication tools: advertising, sales promotions, word of mouth and the sales force. According to the results obtained, the degree of influence attributed to these various communication tools in the buying decision does not differ significantly in terms of socio-demographic categories. On the other hand, the purchase volume of NP/HW/PS is significantly dependent on the influence of advertising and sales promotions in the purchase decision. Furthermore, impulse buying of NP/HW/PS is significantly dependent on the influence of advertising, promotions and WOM.

We conclude that the Portuguese Pharmacies card indeed contributes to customer loyalty in the establishments where it is present. In order to meet customer expectations, a loyalty program should be adjusted over time, seeking to stimulate the satisfaction and reliance in this program.
\end{abstract}

Keywords: Consumer Behaviour; Loyalty; Loyalty Programs; Relationship Marketing; Satisfaction

Article Classification: Research paper 
[Type text]

\section{Introduction}

The marketing environment has suffered, over the years, several modifications. In an increasingly dynamic and complex business world, the growing interest in strategies aimed at a more relational approach between the companies and their customers is boosted - (Belanche et al., 2013), (Nguyen \& Mutum, 2012). This is the context in which the notions of Relationship Marketing and loyalty programs emerge.

Loyalty programs are important strategic tools with regard to customer relationship management, since they are implemented by the companies in order to create, develop and maintain individualized and interactive relationships with those customers considered most important, thus encouraging their loyalty to the company - (Lacey, 2009) and (Meyer-Waarden, 2008). These programs include various Relationship Marketing tools.

The Relationship Marketing view values the creation, maintenance and optimization of a long-term relationship between the company and its customers. This is done so that they remain loyal to the organization and the company is able to understand what their individual needs are. Thus, a differentiated marketing strategy is created based on the development of proposals that meet those specific needs - (Agariya \& Singh, 2011), (Morrisson \& Huppertz, 2010), (Nguyen \& Mutum, 2012), (Pepe, 2011), (Ryals, 2008), (Williams, 2012).

Given the growing concern of the companies in establishing long-term relationships with their customers, and in understanding and meeting their various needs, it is expected that the investment in loyalty programs will be increasingly a priority for the organizations. These programs, and more specifically the loyalty cards, have been implemented on a global scale, representing today a very visible reality in the corporate world and in various business sectors, namely retail trade. In terms of type stores we can mention hypermarkets/supermarkets, petrol stations, cosmetic shops, and also pharmacies.

The primary goal of the investigation is to analyse the influence the "Portuguese Pharmacies card" (PP card) has on the behaviour of pharmacy customers. It also intends to examine whether the consumer's buying behaviour is influenced by marketing stimuli when using the PP card, namely when purchasing non-prescription drugs/health and wellness products/pharmaceutical services (NP/HW/PS). Furthermore, we investigate the relationship between consumer profiles (socio-demographic characteristics), and both purchase decisions and customer loyalty.

\section{Literature review}

\section{Customer Relationship Management}

For the companies it is increasingly more important to develop their competitiveness level, and so managing their relationship with their customers represents a key piece (Foss et al., 2008).

The recognition by the organizations that customers play a key role in their success, and the need the companies have to concentrate on maintaining and focusing on their individual customers has led to the development of database technologies. This is how the concept of CRM, more specifically Customer Relationship Management, appeared at the beginning of the 90 s (Kim et al., 2012). 
According to (Frow \& Payne, 2009) the CRM is the strategic management of the relationship with the customers, based on the appropriate use of technology. The implementation of CRM has allowed companies to store various information about their customers, which has been used as a way to meet their individual needs and succeed in establishing more interactive and mutually beneficial relationships (win-win) between the organizations and their customers. The CRM combines marketing techniques with information technologies with the aim to maintain and establish a relationship with the customer supported by an in-depth use of databases (Nguyen \& Mutum, 2012).

According to (Kim et al., 2012), the goals an organization intends to achieve with the implementation of CRM are: to build and establish a relationship with the customer in a long-term perspective; to develop and maintain an individualized relationship based on customer satisfaction, and succeed in increasing their retention.

Over the years this tool has proven to be a key element with regard to increasing a company's profitability, as it helps to identify which clients of the organization contribute the most to that growth. As such, and so that the implementation of CRM is successful, it is essential to establish a good relationship between the organization and its customers, based on a constant exchange of information (Nguyen \& Mutum, 2012). Thus, the value created by using the CRM has a double aim: the creation of value to the customer but also to the organization (Kim et al., 2012).

Retail loyalty programs have become more increasingly sophisticated through the application of customer relationship management systems (Kim et al., 2013).

\section{On purchase behavior and loyalty programs}

\section{Satisfaction}

Consumer satisfaction represents, in the last two decades, a pillar and a strategic imperative for the organizations where the focus is directed to the client (Luo \& Homburg, 2007). It is thought that satisfaction derives, in large part, from a positive evaluation the customers make on their consumer experience, with this very experience creating and providing a level of pleasure to the customers themselves - (Curran et al., 2010), (Walsh et al., 2008). This refers more specifically to the idea that satisfaction is triggered on the basis of a comparison process between the performance perceived by the customer when using a specific product or service, and their initial expectation about their consumer experience before making that purchase (Belanche et al., 2013). Thus, according to (Brunner et al., 2008), if after the comparison it is discovered that the performance exceeds the customers' expectations, then their satisfaction increases. If the reverse situation occurs the customer satisfaction level decreases, which gives rise to the concept of dissatisfaction.

In recent years several studies have been developed on the subject of consumer satisfaction. In these studies it is suggested that satisfaction is a factor that precedes customer retention and loyalty - (Luo \& Homburg, 2007), (O'Sullivan \& McCallig, 2012). It is also mentioned that there is a positive relation between customer retention and their satisfaction (Keiningham et al., 2007), and between consumer loyalty and their satisfaction - (Nguyen \& Mutum, 2012), (Brunner et al., 2008) - since both retention and loyalty increase with customer's satisfaction, which can lead to future purchase intentions - (Luo \& Homburg, 2007), (Curran et al., 2010). 
Regarding the specific case of pharmacies, it was in the early 90s that researchers began to analyse the importance of user satisfaction (Tinelli et al., 2011). Thus, (Panvelkar et al., 2009) have considered that user satisfaction can lead to a more efficient use of a pharmacy's resources. This is an important element also, since it allows the assessment of the feasibility of the services provided in a pharmacy; to identify which services should be improved; and to continuously monitor the quality of those services in order to improve them. In this way, there is a greater propensity for satisfied users to choose to continue to enjoy those services, and to develop and maintain a long-term relationship with the organization.

Trust

In the last decade the concept of trust has triggered the attention of many researchers in the field of Marketing (Nguyen et al., 2013). Trust is considered to exist when one party believes in the reliability and the honesty of the other party involved in the relationship - (Grayson et al., 2008), (Aurier \& N'Goala, 2010). This explains the growing importance given to customer trust by those companies that have a direct impact on the health of the consumer, such as pharmacies, (Perepelkin and Di Zhang, 2011). In a more specific way we may note that, in Marketing, trust is generally associated with the expectations the consumers have regarding the organization's ability to deliver on their promises and fulfil their obligations (Nguyen et al., 2013)

Trust represents therefore a key element for Relationship Marketing ((Kim et al., 2012); (Aurier \& N'Goala, 2010) more specifically in terms of consumer behaviour as well as their expectations and attitudes (Kim et al., 2012). This is evident in various studies stating that trust can have an immediate effect in the process of customer decision-making and positively influence consumer behaviour and attitudes (Chen et al., 2008), namely with regard to their purchase intentions for a specific product or service, as well as their loyalty to a given company (Nguyen et al., 2013).

It is, thus, mentioned that "trust is the basis of loyalty" (Evanschitzky et al., 2012), since a customer's trust allows the development and maintenance of their loyalty. It is said as well that besides existing a positive relation between customer trust and loyalty, both behavioural and attitudinal, also their satisfaction is closely related to trust (Grayson et al., 2008); (Evanschitzky et al., 2012)).

The trust concept is associated with multiple benefits, among which we highlight the fact that it allows the strengthening of the cooperation and the collaboration between the elements of the relationship, which enables a reduction of the feelings of uncertainty that may arise; encourages the investment in long-term relationships, since consumer trust tends to increase over time as they become increasingly more experienced and knowledgeable of the organizational practices; helps to increase and strengthen the commitment established between customers and the company; and allows the improvement of the quality of the relationship, since trust plays an important role in solving any "misunderstandings" that may occur between the customer and the organization - (Grayson et al., 2008), (Kim et al., 2012); (Williams, 2012).

Therefore, (Grayson et al., 2008) consider that in order to maximize the effects of the trust which is established between the organization and its customers, companies may choose to implement a favourable communication with their customers; meet their needs whenever possible; and promote and demonstrate the benefits inherent to a relationship established on the basis of mutual trust. 


\section{Loyalty}

Customer loyalty is the result of a successful marketing strategy in markets where there is a significant competitiveness, thus still managing to create value for the customer (Li \& Green, 2011). According to (Gee et al., 2008), loyalty is both a long-term attitude and a behavioural pattern reinforced by multiple experiences over time.

When a consumer is regarded as loyal, this loyalty may be related to a company, a brand, a loyalty program, or even to the company's employees (Evanschitzky et al., 2012). Loyal consumers expect to receive preferential treatment from the company, greater recognition, and products/services with higher quality standards than those set by the organization, which can lead to a lower likelihood of the consumers choosing the competition's offer (Morrisson \& Huppertz, 2010); (Pepe, 2011)).

Customer loyalty plays therefore an essential role in the companies, and its many benefits regarding the organizational success are widely recognized - (McMullan \& Gilmore, 2008); (Brunner et al., 2008)). There are numerous reasons justifying the importance of customer loyalty, such as allowing the business to continue as well as growing due to the contribution loyal customers have in increasing the company's profitability - (Evanschitzky et al., 2012); (McMullan and Gilmore, 2008), (Li \& Green, 2011); they are more likely to convey to potential clients a positive image of the organization, through word-of-mouth advertising ((Gee et al., 2008); (Pepe, 2011)), making it possible to reduce marketing operating costs, as some paid communication needs are replaced by word-of-mouth (Brunner et al., 2008); loyal customers have greater willingness to pay a higher price for the company's products/services, and are less price sensitive ((Gee et al., 2008); (Keiningham et al., 2007)); they are more reluctant to leave the organization in favour of the competition ((McMullan \& Gilmore, 2008); (Curran et al., 2010)); and customers loyal to a company are more tolerant regarding any faults that may occur (Curran et al., 2010).

\section{On loyalty programs}

\section{The concept of loyalty programs}

The growth of new information technologies together with the implementation of a marketing strategy oriented towards customer focus, created in the companies a need to develop relationship marketing tools that encourage loyalty. This is the case of customer relationships management programs, more specifically known as loyalty programs or rewards programs - (Dorotic et al., 2012); (Meyer-Waarden, 2008); (Nguyen \& Mutum, 2012)).

These programs have attracted the attention of several marketing researchers (Furinto et al., 2009), especially in the last decade (Demoulin \& Zidda, 2008), and today are considered key tools for the companies that focus on understanding what their customers are interested in and in meeting their needs (Dorotic et al., 2012).

In order to retain customers and reward their behaviour, the organizations have adopted various strategies. The most used is the implementation of loyalty programs, since these help to increase customer loyalty and consequently the company's long-term profitability ((Furinto et al., 2009); (Gandomi \& Zolfaghari, 2013).

According to (Dorotic et al., 2012) and (Henderson et al., 2011) these programs include a wide range of marketing actions, while literature describes loyalty programs in different ways. We can highlight several - reward programs, shopping programs, frequency reward programs, and loyalty cards -, but it is important to note that a company can 
offer different loyalty programs, at the same time, without the launching of one program causing the failure of another (if the existing loyalty program is of quality, then it is quite likely that it will remain in the market (Demoulin \& Zidda, 2008).

In view of this, and although in marketing literature there are various definitions of the concept of loyalty programs, the common and central point to them all relates to the fact that the main goal of these programs is to reward and encourage the customers to adopt a loyal behaviour towards the organization (Dorotic et al., 2012); (Bridson et al., 2008); (Morrisson \& Huppertz, 2010), by making repeated purchases ((Demoulin \& Zidda, 2008); (Gandomi \& Zolfaghari, 2013).

The concept of loyalty programs can then be defined as a system of incentives offered by the company in order to improve the customer's consumer behaviour over time (Henderson et al., 2011). More specifically, these programs represent an integrated system of marketing actions developed by the companies in order to offer incentives and rewards with the primary purpose of making the customers more loyal towards the organization, thus providing them greater satisfaction - (Furinto et al., 2009); (Leenheer et al., 2007).

\section{The impact of loyalty programs in companies and customers}

(Leenheer et al., 2007) believe that loyalty programs can increase and ensure customer loyalty, based on economic, psychological and also sociological mechanisms and factors.

According to the economic factors, we can state the fact that loyalty programs are recognized as value given to the customers in the form of rewards. Associated with the economic factors there is also the concept of switching costs, since if customers choose the products/services of another company then they are losing value ((Morrisson \& Huppertz, 2010); (Leenheer et al., 2007).

With regard to the psychological factors it is important to highlight the fact that, in general, customers value and appreciate the rewards given to them, since loyalty programs transmit the feeling to the customers that they are being recognized and valued when compared to other customers. This may lead to the feeling that they are a special client, and as such this can trigger and encourage the consumer to adopt a more loyal behaviour towards the organization (Furinto et al., 2009); (Morrisson \& Huppertz, 2010); (Mimouni-Chaabane \& Volle, 2010); (Leenheer et al., 2007).

As for the social effects we can note the fact that the need to belong to a specific group is an intrinsic characteristic of individuals. Loyalty programs require the creation of exclusive customer groups, and the identification and sharing of values with a company or a specific brand is increasingly recurring. Therefore, there is a greater predisposition, and even motivation, from the customers to belong to these groups, which are generated by loyalty (Mimouni-Chaabane \& Volle, 2010); (Leenheer et al., 2007)).

Because the concepts of satisfaction and loyalty are positively related (Gandomi \& Zolfaghari, 2013) those authors believe that customer satisfaction is a key factor with regard to the effectiveness of a specific loyalty program, since a dissatisfied customer does not understand the program in the same way a satisfied customer would.

Loyalty programs are an important element because they strengthen the relationship between the customers and the companies; increase customer loyalty ((Bridson et al., 2008); (Mimouni-Chaabane \& Volle, 2010)), and consequently 
promote the increase of their satisfaction. There is, therefore, a greater likelihood of the customer accepting to participate in and interact within the program. This fact leads to a positive impact on the organization's sales, and on the number of visits the customers pay to the store, as well as their retention ((Bridson et al., 2008); (Lacey, 2009).

Besides satisfaction being one of the reasons leading a customer to participate in a loyalty program there is another reason influencing that decision, which is linked to the fact that the customer assesses the potential benefits of joining the program when compared to costs that it may generate ((Dorotic et al., 2012); (Mimouni-Chaabane \& Volle, 2010). Therefore, the probability of a customer choosing to join the loyalty program will depend on the effort that they will have to make in order to achieve the benefits offered. More specifically, there is a greater likelihood the customers will take part in the loyalty program if the compensation they foresee receiving outweighs the costs of their participation (Dorotic et al., 2012); (Rese et al., 2013), (Leenheer et al., 2007).

According to (Rese et al., 2013), this issue can be more easily understood with the following example: a customer wants to purchase a product that is available both in company A and company B. However, company A has a customer loyalty program, unlike company B who does not offer any program. The critical situation occurs when the product offered by company B is more advantageous than the one from company A, but the benefit from the customer's participation in company A's loyalty program outweighs the offer from company B, which motivates the client to choose to buy the product from company A.

(Mimouni-Chaabane \& Volle, 2010) consider that the benefits of a customer's participation in a loyalty program are related to the fact they have an opportunity to save and spend a smaller sum of money in their future purchases; are able to save time and effort when carrying out their choices; feel favoured because they obtain a preferential treatment and status over other customers; feel they belong to a group that shares the same values; are able to try new products, and enjoy unique experiences only available for customers who joined the program.

Despite the many advantages a loyalty program can provide to the companies implementing it and to the customers participating in it, there are certain factors that can lead to failure, or even to the cancellation of a loyalty program. One of the reasons explaining this situation is related to the fact that the first company to implement a successful loyalty program has a high risk of being imitated by other companies, and as such the results the pioneering organization would want to obtain may not be achieved. Another reason that allows us to understand this situation is associated with the fact that loyalty programs are sometimes poorly designed, or require great efforts from the customers, which motivates them to automatically stop participating in the program (Demoulin \& Zidda, 2008).

\section{Loyalty cards}

Loyalty programs have a diversified set of marketing tools associated with them, being loyalty cards one of the most commonly implemented tools by the companies. Loyalty cards enable the companies to get a competitive advantage in the market, since they encourage the customers to make repeated purchases from the same company and allow it to obtain information and knowledge about their customers, therefore developing a more consistent relationship with them ((Demoulin \& Zidda, 2008); (Henderson et al., 2011); (Walsh et al., 2008)).

Loyalty card programs are an integrated system of marketing actions with the aim to make the customers become more loyal to a specific company. This is based on the development of personalized relationships between the organization 
and its customers (Meyer-Waarden, 2008), which are more effective when the customer does not have other cards from the competition, since this makes it less likely that the customer will purchase products/services from other stores (Demoulin \& Zidda, 2008).

According to (Meyer-Waarden, 2008), the implementation of a loyalty card program has a key goal that is extremely important for the organizations, as it allows them to select, identify and target the more important customers, so that they can subsequently make a better distribution of the available resources. So, through loyalty cards the companies have the opportunity to individualize their customers based on the marketing mix policy, since in this way they can, for example, identify those customers more sensitive to the price changes of a certain product/service.

However, other reasons explain the importance of the implementation of a card program. They also allow the business volume of the company to expand; increase their customers' loyalty through incentives and benefits provided by the organization, and consequently their levels of satisfaction; increase the customer lifetime value; and reduce the customers' interest in the offer of the competition - (Ashley et al., 2011); (Henderson et al., 2011).

When participating in a loyalty card program the customers also get some advantages. Of note is the fact that this participation allows the customers to reduce the demand for information about a specific product/service, because the use of the card encourages customers to purchase their goods from the company offering the loyalty program (Walsh $e t$ al., 2008). Thus, the customers with cards are more likely to remain loyal to the company, to purchase the products of that company more frequently and in larger quantities, and progressively to feel less attracted by promotions from other organizations (Meyer-Waarden, 2008).

Loyalty cards should therefore create value for their users, as customers use the card and are faithful to the program only if they recognize that their participation provides them with benefits (Demoulin \& Zidda, 2008). This can be reinforced by the idea that even when customers are dissatisfied, if they consider that the card gives them significant advantages then there is a high likelihood that they will use it (Walsh et al., 2008).

\section{The pharmacist's role}

The exploration of the concept of Relationship Marketing has appeared in literature in different contexts, and is approached in different sectors (Agariya \& Singh, 2011). In the pharmaceutical context the approach of Relationship Marketing is to attract, maintain and improve the relations and interactions between the client (more specifically, the user) and the organization (the pharmacy) so as to generate mutual benefits, both for the pharmacist and the user. This perspective emphasizes, therefore, the interest in developing and maintaining a lasting relationship with the user; it allows the pharmacist to create strategies to encourage the user's active participation throughout the interaction, and values the importance of a relationship based on empathy and trust between the customer and the pharmacist so that the relationships established are successful (A.Ph.A. (American Pharmacists Association), 2007).

The pharmaceutical industry has continuously increased their marketing spending. The impact of marketing activities on pharmaceutical sales is worthy of investigation. In recent years, marketing scholars appear to have become much more interested in pharmaceutical marketing (Stros \& Lee, 2015). 
[Type text]

The pharmacist's role has changed over the past two decades, since in addition to the selling of pharmaceutical products the importance the pharmacist has in developing and maintaining a relationship with the customers is appreciated and emphasized (Panvelkar et al., 2009).

In this sense, Relationship Marketing provides a set of strategies for the pharmacist to be able to maintain a relationship with the users. For that purpose it is necessary to consider a set of preconditions for building and maintaining those relationships. First, and before the release of a specific activity, the pharmacy must determine whether its employees have the necessary skills to meet the users' expectations and needs. Then, in order to meet those expectations, the pharmacy must rely on qualified staff to ensure the quality of its activities. Finally, the users should be encouraged to share their experiences regarding the activity with the pharmacy (A.Ph.A, 2007).

\section{Proposed Research}

\section{Portuguese Pharmacies Card}

The proposed research addresses the impact of the adoption of the Portuguese Pharmacies card.

The Portuguese Pharmacies Program is currently available in most pharmacies in Portugal, and the Portuguese Pharmacies card represents this program's instrument best known to the customers (Portuguese Pharmacies, 2013a). The card was implemented in 2008, and until October of 2013 1,985,740 cards were issued. The cards issued in the year of release represent $29.9 \%$ of the total cards issued, and considering the first three years $(2008 / 2010)$ that percentage rises to $65.6 \%$.

Of the total cards issued $81 \%$ were registered to women, with those issued to men representing only $19 \%$.

The Portuguese Pharmacies card offers several advantages for its users, and can work in two different ways: as a card that enables an accrual of advantages through the accumulation of points, and as a bank card that in addition to accumulating points serves as a form of payment. It's the user decision to choose the type that better suits their needs.

Of the total cards issued in the period $2008 / 2013,99.5 \%$ correspond to the advantage accrual cards, while the bank cards represent $0.5 \%$ of all cards issued.

The advantage accrual card allows the user to accumulate points when purchasing non-prescription drugs, health and wellness products, and pharmaceutical services, being prescription drugs excluded for the purpose of point accumulation. It is however worth mentioning that with regard to using the points they can only be exchanged for nonprescription drugs, health and wellness products, and pharmaceutical services. 
[Type text]

Research hypothesis

Taking into account the literature review, we focus on the following research hypotheses:

H1) Marketing stimuli influence consumers' buying behavior when using the PP card with regard to NonPrescription medicines / Health and Wellness product / Pharmaceutical Services (NP/HW/PS)

H2) The influence of Marketing stimuli on purchase decisions (self-declared) depends on socio-demographic characteristics of consumers

H3) There is a positive relationship between satisfaction and buying behavior when using the PP card

H4) There is a positive relationship between trust and the buying behavior when using the PP card

H5) Buying behavior when using the PP card depends on socio-demographic characteristics

The variables considered in the research hypotheses are depicted in Table 1.

Table 1 - Research target variables

\begin{tabular}{|l|l|}
\hline Marketing stimuli: & Socio-demographics: \\
\hline a) Advertising & a) Gender \\
b) Promotions & b) Age \\
c) WOM & c) Qualifications \\
d) Sales force/Pharmacists & d) Profession \\
& e) Number of household members \\
\hline Buying behavior: & f) Household income \\
\hline a) Purchases volume & Antecedents of Loyalty: \\
b) Unplanned purchases & a) Satisfaction \\
c) Unusual purchases & b) Trust \\
\hline
\end{tabular}


[Type text]

\section{Methodological approach}

\section{Research instrument}

In order to address the research hypotheses, data is collected through a questionnaire survey.

The questionnaire structure includes three distinct groups of questions: 1) "Loyalty, satisfaction and trust"; 2) "Consumer buying behavior"; 3) "Socio-demographic characterization of the respondent".

In group 1) we identify customers who have joined the Portuguese Pharmacies card and question them if they feel pleased for having joined the card and also if they feel confident using it.

Group 2) refers to the influence that the various communication tools have on consumers purchases of (NP/HW/PS) in Portuguese Pharmacies and to buying behavior when using the PP card.

Likert 5-point scales are adopted in groups 1) and 2) for measuring degree of agreement (1 - Strongly disagree; 2 - I disagree in part; 3 - Neither agree nor disagree; 4 - Somewhat agree; 5 - totally agree) and degree of influence (1 - No influence; 2 - Very little influence; 3 - Little influence; 4 - Some influence; 5 - A lot of influence). For example; in group 2 ), the respondents are requested to report their degree of agreement with the indicators of:

- Purchases volume: "I acquire NP/HW/PS in larger quantities to earn points"

- Unplanned purchases: "I make unplanned purchases of NP/HW/PS to earn points"

- Unusual purchases: "I make unusual purchases of NP/HW/PS to earn points"

A first pre-test is carried out with a group of 35 individuals, in order to look for their views on the clarity of questions and the difficulties experienced when completing the questionnaire. A revised version of the questionnaire is then produced. A second pre-test (also with a group of 35 individuals) supports this revised version.

\section{Sampling and data collection}

Due to practical limitations, we resort to a non-probabilistic sampling process to select the respondents to the questionnaire. To provide information to this sampling procedure sources considered are the Marketing Department of the Program of Portuguese Pharmacies and INE (Portuguese Institute of Official Statistics). Data collected refer to the Distribution of the number of card users until October 2013, Distribution of the number of Portuguese pharmacies until October 2013, Distribution of the Portuguese population, aged 15 years or more in 2012 and Card users, aged 15 years or more. Finally, we conclude that Lisbon and Setúbal districts are the most relevant, always standing out in the referred distributions, and decide to conduct our research in these districts municipalities. 
[Type text]

Table 2 - Population vs sample distribution (per municipality)

\begin{tabular}{|lrr|}
\hline & Population & Sample \\
\hline Lisbon & $20.9 \%$ & $21.0 \%$ \\
\hline Sintra & $14.5 \%$ & $14.5 \%$ \\
\hline Loures & $8.1 \%$ & $8.1 \%$ \\
\hline Cascais & $8.0 \%$ & $8.1 \%$ \\
\hline Amadora & $6.9 \%$ & $7.0 \%$ \\
\hline Almada & $6.8 \%$ & $6.8 \%$ \\
\hline Oeiras & $6.7 \%$ & $6.8 \%$ \\
\hline Seixal & $6.3 \%$ & $6.2 \%$ \\
\hline Odivelas & $5.8 \%$ & $5.7 \%$ \\
\hline $\begin{array}{l}\text { Vila Franca de } \\
\text { Xira }\end{array}$ & $5.3 \%$ & $5.2 \%$ \\
\hline Setúbal & $4.6 \%$ & $4.7 \%$ \\
\hline Barreiro & $3.1 \%$ & $2.9 \%$ \\
\hline Mafra & $3.0 \%$ & $2.9 \%$ \\
\hline
\end{tabular}

Since no data was available on the number of card users per municipality, the distribution of Portuguese population (individuals aged 15 years or more in 2012) is considered as a proxy of the target population. It comprises 2.162.316 individuals.

Data collection took place between mid-January and February 2014 and covered several Portuguese pharmacies located in 13 municipalities of the metropolitan area of Lisbon, reaching a sample of 385 individuals- see Table 2. Surveys were conducted on different days of the week and different operating hours of pharmacies in order to obtain a heterogeneous sample reflecting the diversity of consumers.

\section{Data analysis and empirical evaluation of research hypothesis}

\section{The respondents profile}

The 385 respondents socio-demographic characteristics are summarized in Table 3.

Among respondents, the number of household members ranges from 1 to 7 with average around 3 and 1.2 standard deviation. The household income distribution is depicted in Figure 1.

Comparing the sample results to the target population information we find some discrepancies: in the population women represent 53.7\%; older people, over 65 years, are under-represented in the sample $(14.3 \%$ vs. $23.4 \%$ in the population); individuals with higher education are over-represented (they account for $25.6 \%$ in the population); there is also an important difference between the percentage of active individuals in the sample $(78.7 \%)$ and the active population (58.9\%), 
[Type text]

Table 3 - The respondents profile

\begin{tabular}{|lc|}
\hline & Percentage \\
\hline Female & 56.9 \\
\hline 45 - 54 years & 22.9 \\
\hline 55 - 64 years & 23.6 \\
\hline Basic education 3 (9 years) & 23.4 \\
\hline Secondary education (12 years) & 11.7 \\
\hline Post-secondary education & 25.7 \\
\hline Higher education & 10.9 \\
\hline Middle to Upper Management & 36.1 \\
\hline Technician / Smallholder & 29.6 \\
\hline Administrative services / Sales & 14.0 \\
\hline Retired/ Work at home & 15.6 \\
\hline Lisboa & 18.4 \\
\hline Sintra & 21.0 \\
\hline
\end{tabular}

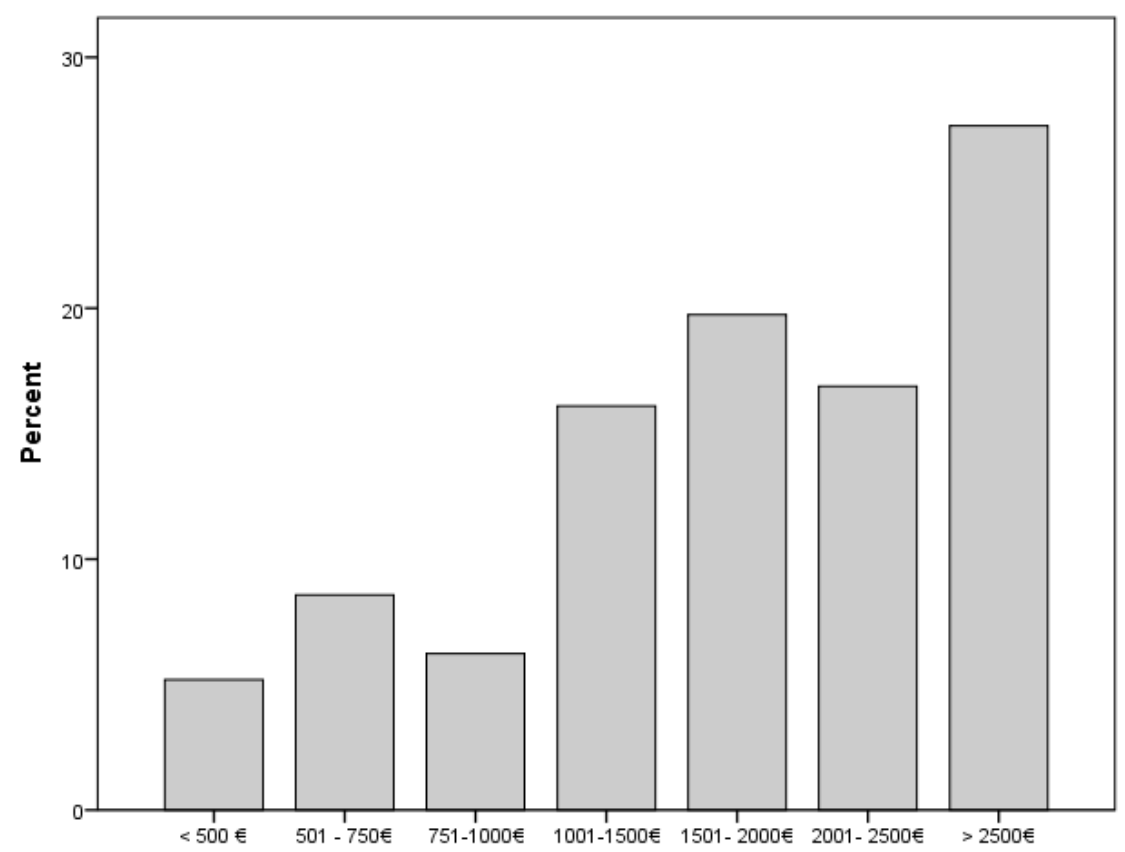

Figure 1 - Household monthly income distribution

Did you adhered to the Portuguese Pharmacies card?

Yes

Around 59\% of respondents (223) have already adhered to the PP card and they did it for various motives -Table 4. The vast majority of respondents (98.2\%) adheres to the "Benefits" PP card type (card for accumulating points only) while those joining the "Bank" card type are very few. 
Table 4 - Main reason for joining the card

\begin{tabular}{|lc|}
\hline & Percent \\
\hline The Pharmacy I usually go to adhered to the PP card & 38.8 \\
\hline I can use PP card at any Portuguese Pharmacy & 8.4 \\
\hline Points in the card are valid during a year & 2.2 \\
\hline Using the card has several advantages & 25.6 \\
\hline Products I buy the most are NP/HW/PS which enable to earn points & 5.3 \\
\hline I can deduct the card points in several NP/HW/PS & 18.1 \\
\hline I receive an extra point when visiting a PP for the first time during the day & 0.9 \\
\hline Another motive & 0.9 \\
\hline Total & 100.0 \\
\hline
\end{tabular}

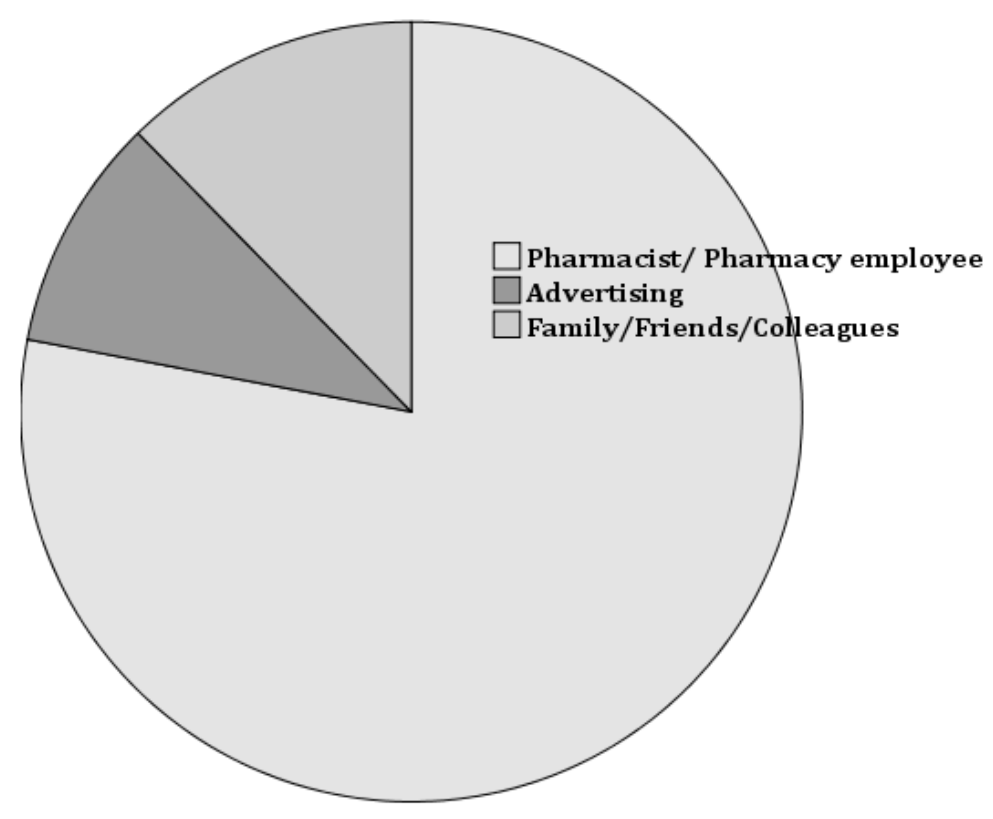

Figure 2 - How did you hear about the card

Most joined the card one or two years ago (45.4\%) and heard about it from the Pharmacist or Pharmacy employee (78\%). They accumulate points in the card due to purchases of health and wellness products: the majority (44.7\%) accumulated 1-10 points and $41.5 \%$ accumulated $11-50$ points. 
[Type text]

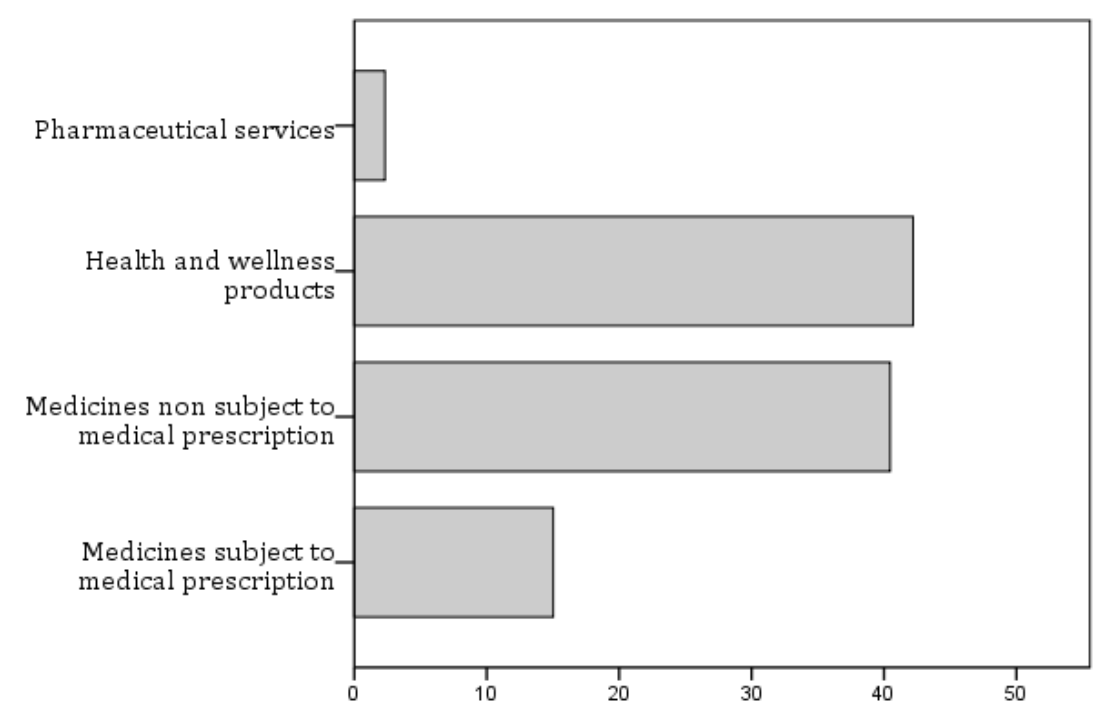

Figure 3 - Products that enable to accumulate more points on the card

No

The main reason for not using PP card is simply being unaware of it. Also, some customers tend to think that the card benefits do not justify membership or that they prefer immediate rewards - Table 5.

Table 5 - Main reason for not joining the card

\begin{tabular}{|lc|}
\hline & Percent \\
\hline Unaware of the card & 36.7 \\
\hline Benefits do not justify membership & 15.8 \\
\hline I am not a regular PP customer & 9.5 \\
\hline I have other pharmacy card & 8.2 \\
\hline Conditions of use / adherence are unclear & 3.8 \\
\hline I prefer immediate rewards & 12.7 \\
\hline Another reason & 13.3 \\
\hline Total & 100 \\
\hline
\end{tabular}

Consumers behavior

Overall, the customers with PP card are very satisfied and have confidence in it. In Table 6 this positive views are illustrated by the medians of satisfaction and trust items and we may also note that the distributions of these indicators are skewed to the right. 
Table 6 - Satisfaction and trust on the Portuguese Pharmacies card

\begin{tabular}{|lc|}
\hline Satisfaction & Median \\
\hline Joining the card was a good choice & 5 \\
\hline Using the card has been positive & 4 \\
\hline When using the card I feel that I am rewarded & 4 \\
\hline The advantages to using the card surpassed what I had envisioned & 4 \\
\hline I intend to continue to use the card & 5 \\
\hline I recommend joining the card & 5 \\
\hline Overall I am very pleased to have joined the card & 5 \\
\hline Trust & 5 \\
\hline I provided data to adhere to card without hesitation & 5 \\
\hline I relied on information gathered and received to join the card & 4 \\
\hline I feel that my data is kept confidential when using the card & 4 \\
\hline I think I'll always benefit from the advantages of using the card & 5 \\
\hline Overall I feel great confidence in using the card & \\
\hline
\end{tabular}

The respondents answers concerning satisfaction with the PP card can be summarized via a Principal Components Analysis - ACP. The Kaiser-Meyer-Olkin measure regarding satisfaction items is 0.890. The first (Varimax rotated) component extracted accounts for around 51\% of total variance and relates to overall satisfaction with the card; the second (rotated) component explains around $21 \%$ of total variance and refers to "The advantages to using the card surpassed what I had envisioned".

Kaiser-Meyer-Olkin is 0.813 for trust items. Using ACP, these items can be summarized into a unique component that explains $67 \%$ of total variance.

Concerning the buying behavior when using the PP card, most respondents strongly disagree with:

- I acquire NP/HW/PS in larger quantities to earn points (44\%)

- I make unplanned purchases of NP/HW/PS to earn points (63\%)

- I make unusual purchases of NP/HW/PS to earn points $(63 \%)$

Consumers acknowledge the extent of the effects that the diverse Marketing stimuli can have on them (1 - No influence; 2 - Very little influence; 3 - Little influence; 4 - Some influence; 5 - A lot of influence). According to theirs answers, the relationship with the pharmacist clearly stands out (exerts more influence), followed by sales promotions (median is 4), while advertising and WOM are secondary (median 3). 
[Type text]

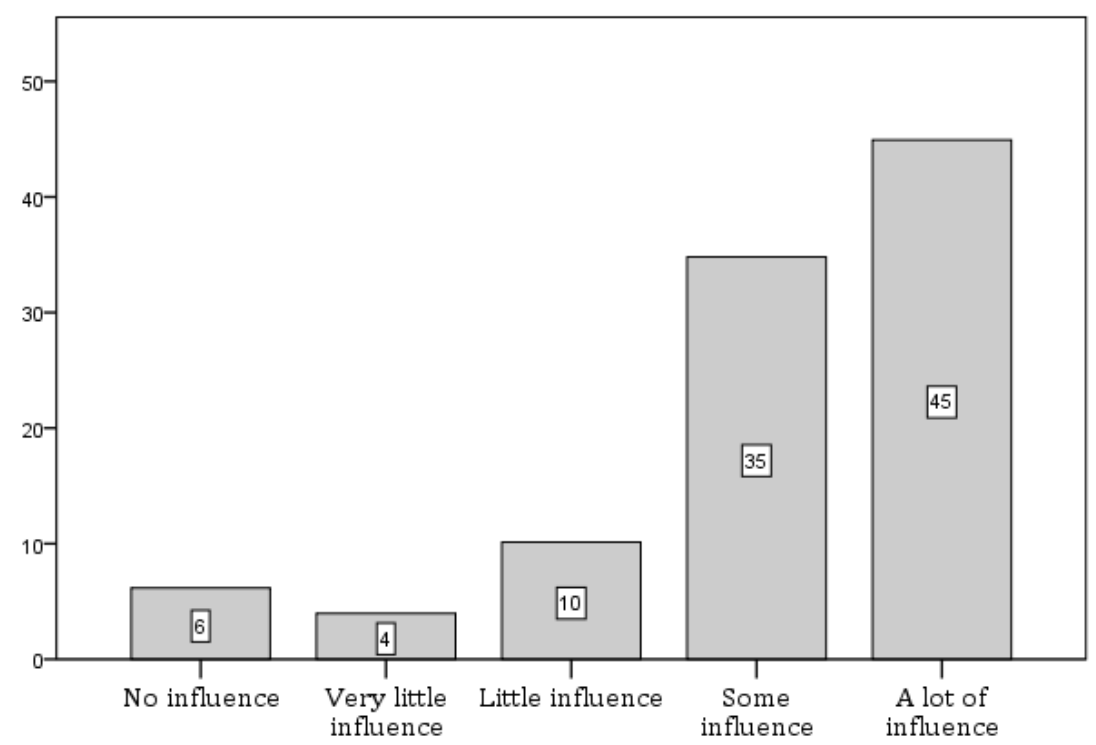

Figure 4 - Relationship with the pharmacist

Research hypothesis

In this section, the relationships stated in the research hypothesis (see 0 and Table 1 ) are empirical evaluated resorting to appropriate measures of association. Although the sample considered is non-probabilistic we opt for providing measures of associations when corresponding p-values are below 0.05 .

H1) Marketing stimuli influence consumers' buying behavior with regard to Non-Prescription medicines / Health and Wellness product / Pharmaceutical Services (NP/HW/PS)

The Marketing stimuli (Advertising, Sales promotions, Recommendations from another customer and Relationship with pharmacist) have a significant impact on consumers' buying behavior according to Spearman correlation coefficients (all p-values are below 0.05) - Table 7.

Table 7 - Significant Spearman correlations between Marketing stimuli and consumers' buying behavior

\begin{tabular}{|lcccc|}
\hline ...to earn points in the card & Advertising & Promotions & Recommendations & Relationship \\
\hline I acquire NP/HW/PS in larger quantities ... & 0.300 & 0.382 & 0.167 & 0.245 \\
\hline I make unplanned purchases of NP/HW/PS ... & 0.324 & 0.373 & 0.228 & 0.209 \\
\hline I make unusual purchases of NP/HW/PS ... & 0.327 & 0.327 & 0.141 & 0.197 \\
\hline
\end{tabular}

H2) The influence of Marketing stimuli on purchase decisions (self-declared) depends on socio-demographic characteristics

Measures of association between the degree of influence of Marketing stimuli and socio-demographics, reveal some relevant relationships - see Table 8 and Figure 5. For example: the increase in academic qualifications tends to diminish the influence of the relationship with pharmacist. 
Table 8 - Significant relationships between Marketing stimuli and socio-demographics

\begin{tabular}{|lcccc|}
\hline & \multicolumn{3}{c}{ Spearman correlations } & Cramer's V \\
\hline & Age & Qualifications & Income & Gender \\
\hline Advertising & -0.245 & -- & -- & 0.281 \\
\hline Sales promotions & -0.233 & -- & -- & 0.219 \\
\hline Recommendations from another customer & -0.169 & -- & -- & -- \\
\hline Relationship with pharmacist & -- & -0.197 & -0.233 & -- \\
\hline
\end{tabular}

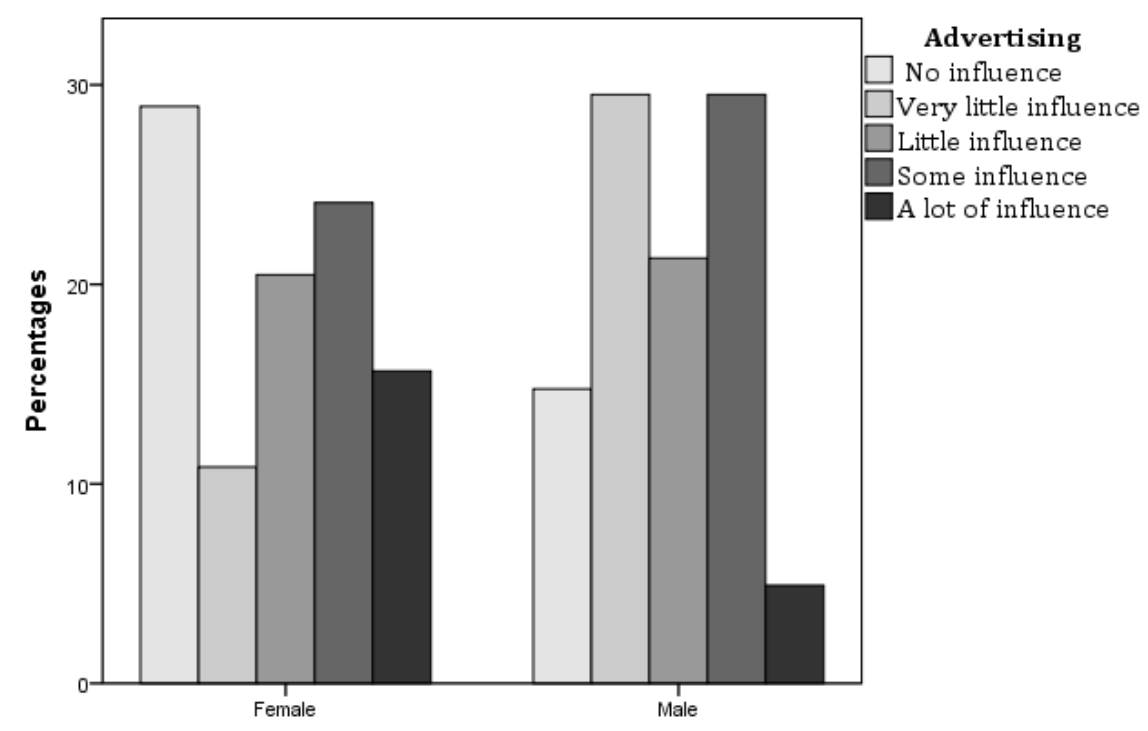

Figure 5 - Advertising influence and Gender

H3) There is a positive relationship between satisfaction and consumers' buying behavior with regard NP/HW/PS

According to the association between the principal components of satisfaction and the three indicators of consumers' buying behavior there is only one specific association worth to mention - the relationship between the general indicator of satisfaction (first component) and purchases volume (Spearman correlation is 0.134 and the corresponding $\mathrm{p}$-value is 0.043).

H4) There is a positive relationship between trust and consumers' buying behavior with regard to NP/HW/PS

We find no relevant associations between the trust factor (principal component) and consumers' buying behavior.

H5) Consumers' buying behavior with regard NP/HW/PS depends on socio-demographic characteristics

According to Cramer's V there is no relevant association between Consumers' buying behavior with regard NP/HW/PS and Gender or Profession. Spearman correlation coefficients reveal significant negative associations only between purchases volume and Qualifications and Income ( -0.150 and -0.138 , respectively). We conclude that people with higher income and qualifications are not easily persuaded to purchase NP/HW/PS in larger quantities just to earn points in the PP card. 
[Type text]

\section{Contributions and future research}

According to the results obtained, we conclude the following (see Table 1 for the detailed variables' description):

H1) Marketing stimuli influence consumers' buying behavior with regard to Non-Prescription medicines / Health and Wellness product / Pharmaceutical Services (NP/HW/PS).

This conclusion is consistent with the work of (Dorotic et al., 2012) and (Henderson et al., 2011) that point to the fact that loyalty programs include a wide range of marketing stimuli which influence consumers' buying behavior.

H2) The influence of some Marketing stimuli on purchase decisions (self-declared) depends on some socio-demographic characteristics. Specifically, the influence of advertising and sales promotions decreases with age and is more apparent in males; the increase in academic qualifications or income tends to diminish the influence of the relationship with the pharmacist; the influence of recommendations from another customer tends to decrease with age.

H3) There is a positive relationship between the general indicator of satisfaction and the increase of purchases volumes concerning NP/HW/PS.

The fact that customer satisfaction can lead a more efficient use of a pharmacy resources was also noted by (Pankelvar et al., 2009), for example.

H4) No meaningful association is find between trust regarding the PP card and consumers' buying behavior with regard to NP/HW/PS.

H5) Lower income and lower qualifications may entail the increase of purchases volumes with regard to NP/HW/PS but, in general, consumers' buying behavior does not depend on socio-demographic characteristics

This study was exclusively conducted in Portuguese pharmacies (although 69\% of pharmacies have joined the program Portuguese Pharmacies) which means an extrapolation of results to other pharmacies is restricted.

Future research should extend the scope of investigation to other outlets of pharmaceuticals nonprescription / health care and wellness products and relate new results with those obtained in the present study. In particular, points of sale in supermarkets / hypermarkets with loyalty programs should be considered to assess their impact on consumer behavior. 


\section{References}

Agariya, A. K. \& Singh, D. (2011) What really defines relationship marketing? A review of definitions and general and sector-specific defining constructs. Journal of Relationship Marketing, 10, 203-237.

Ashley, C., Noble, S. M., Donthu, N. \& Lemon, K. N. (2011) Why customers won't relate: Obstacles to relationship marketing engagement. Journal of Business Research, 64, 749-756.

Aurier, P. \& N'goala, G. (2010) The differing and mediating roles of trust and relationship commitment in service relationship maintenance and development. Journal of the Academy of Marketing Science, 38, 303-325.

Belanche, D., Casaló, L. V. \& Guinalíu, M. (2013) The role of consumer happiness in relationship marketing. Journal of Relationship Marketing, 12, 79-94.

Bridson, K., Evans, J. \& Hickman, M. (2008) Assessing the relationship between loyalty program attributes, store satisfaction and store loyalty. Journal of Retailing and Consumer Services, 15, 364-374.

Brunner, T. A., Stöcklin, M. \& Opwis, K. (2008) Satisfaction, image and loyalty: new versus experienced customers. European Journal of Marketing, 42, 1095-1105.

Curran, J. M., Varki, S. \& Rosen, D. E. (2010) Loyalty and its antecedents: Are the relationships static? Journal of Relationship Marketing, 9, 179-199.

Demoulin, N. T. \& Zidda, P. (2008) On the impact of loyalty cards on store loyalty: Does the customers' satisfaction with the reward scheme matter? Journal of Retailing and Consumer Services, 15, 386-398.

Dorotic, M., Bijmolt, T. H. \& Verhoef, P. C. (2012) Loyalty Programmes: Current Knowledge and Research Directions*. International Journal of Management Reviews, 14, 217-237.

Evanschitzky, H., Ramaseshan, B., Woisetschläger, D. M., Richelsen, V., Blut, M. \& Backhaus, C. (2012) Consequences of customer loyalty to the loyalty program and to the company. Journal of the Academy of Marketing Science, 40, 625-638.

Foss, B., Stone, M. \& Ekinci, Y. (2008) What makes for CRM system success-Or failure? Journal of Database Marketing \& Customer Strategy Management, 15, 68-78.

Frow, P. \& Payne, A. (2009) Customer relationship management: a strategic perspective. Journal of Business Market Management, 3, 7-27.

Furinto, A., Pawitra, T. \& Balqiah, T. E. (2009) Designing competitive loyalty programs: How types of program affect customer equity. Journal of Targeting, Measurement and Analysis for Marketing, 17, 307-319.

Gandomi, A. \& Zolfaghari, S. (2013) Profitability of loyalty reward programs: An analytical investigation. Omega, 41, 797-807.

Gee, R., Coates, G. \& Nicholson, M. (2008) Understanding and profitably managing customer loyalty. Marketing Intelligence \& Planning, 26, 359-374.

Grayson, K., Johnson, D. \& Chen, D.R. (2008) Is firm trust essential in a trusted environment? How trust in the business context influences customers. Journal of Marketing Research, 45, 241-256.

Henderson, C. M., Beck, J. T. \& Palmatier, R. W. (2011) Review of the theoretical underpinnings of loyalty programs. Journal of Consumer Psychology, 21, 256-276.

Keiningham, T. L., Cooil, B., Aksoy, L., Andreassen, T. W. \& Weiner, J. (2007) The value of different customer satisfaction and loyalty metrics in predicting customer retention, recommendation, and share-of-wallet. Managing Service Quality: An International Journal, 17, 361-384.

Kim, H., Lee, J., Choi, D., Wu, J., Johnson, K. (2013) Perceived Benefits of Retail Loyalty Programs: their effects on program loyalty and customer loyalty. Journal of Relationship Marketing, 12, 95-113.

Kim, M., Eun Park, J., Dubinsky, A. J. \& Chaiy, S. (2012) Frequency of CRM implementation activities: a customer-centric view. Journal of Services Marketing, 26, 83-93.

Lacey, R. (2009) Limited influence of loyalty program membership on relational outcomes. Journal of Consumer Marketing, 26, 392-402.

Leenheer, J., Van Heerde, H. J., Bijmolt, T. H. \& Smidts, A. (2007) Do loyalty programs really enhance behavioral loyalty? An empirical analysis accounting for self-selecting members. International Journal of Research in Marketing, 24, 31-47.

Li, M.-L. \& Green, R. D. (2011) A mediating influence on customer loyalty: The role of perceived value. Journal of Management and Marketing Research, 7, 1-12.

Luo, X. \& Homburg, C. (2007) Neglected outcomes of customer satisfaction. Journal of Marketing, 71, $133-149$.

Mcmullan, R. \& Gilmore, A. (2008) Customer loyalty: an empirical study. European Journal of Marketing, 42, $1084-1094$.

Meyer-Waarden, L. (2008) The influence of loyalty programme membership on customer purchase behaviour. European Journal of Marketing, 42, 87-114.

Mimouni-Chaabane, A. \& Volle, P. (2010) Perceived benefits of loyalty programs: Scale development and implications for relational strategies. Journal of Business Research, 63, 32-37. 
Morrisson, O. \& Huppertz, J. W. (2010) External equity, loyalty program membership, and service recovery. Journal of Services Marketing, 24, 244-254.

Nguyen, B. \& Mutum, D. S. (2012) A review of customer relationship management: successes, advances, pitfalls and futures. Business Process Management Journal, 18, 400-419.

Nguyen, N., Leclerc, A. \& Leblanc, G. (2013) The Mediating Role of Customer Trust on Customer Loyalty. Journal of Service Science and Management, 6, 96-109.

O'sullivan, D. \& Mccallig, J. (2012) Customer satisfaction, earnings and firm value. European Journal of Marketing, 46, 827-843.

Panvelkar, P. N., Saini, B. \& Armour, C. (2009) Measurement of patient satisfaction with community pharmacy services: a review. Pharmacy world \& science, 31, 525-537.

Pepe, M. (2011) Customer lifetime value: A vital Marketing/Financial concept for businesses. Journal of Business \& Economics Research, 10, 1-10.

Perepelkin, J. \& Di Zhang, D. (2011) Brand personality and customer trust in community pharmacies. International Journal of Pharmaceutical and Healthcare Marketing, 5, 175-193.

Rese, M., Hundertmark, A., Schimmelpfennig, H. \& Schons, L. M. (2013) Loyalty program types as drivers of customer retention: a comparison of stand-alone programs and multi-vendor loyalty programs through the lens of transaction cost economics. The International Review of Retail, Distribution and Consumer Research, 23, 305323.

Ryals, L. (2008) Determining the indirect value of a customer. Journal of Marketing Management, 24, 847-864.

Stros, M. \& Lee, N. (2015) Marketing dimensions in the prescription pharmaceutical industry: a systematic literature review. Journal of Strategic Marketing, 23, 318-336.

Tinelli, M., Blenkinsopp, A. \& Bond, C. (2011) Development, validation and application of a patient satisfaction scale for a community pharmacy medicines-management service. International Journal of Pharmacy Practice, 19, 144155.

Walsh, G., Evanschitzky, H. \& Wunderlich, M. (2008) Identification and analysis of moderator variables: investigating the customer satisfaction-loyalty link. European Journal of Marketing, 42, 977-1004.

Williams, K. C. (2012) Core qualities of successful marketing relationships. Journal of Management and Marketing Research, 10, 1-29. 
[Type text] 